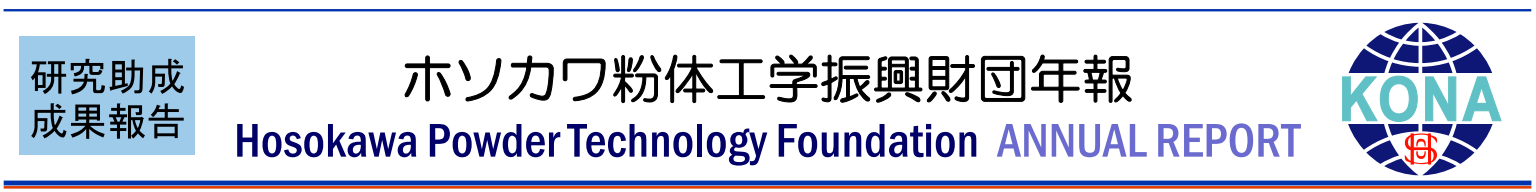

16107

\title{
ナノクリスタルを基盤とした機能性吸入粉末剂の創製 \\ Development of Functional Dry Powder Formulations for Inhalation, Based on Nanocrystals
}

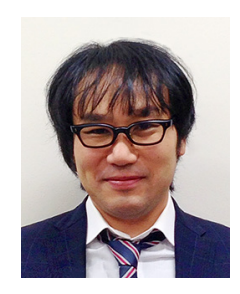

\author{
研究代表者 Research leader：奥田 知将 Tomoyuki OKUDA \\ 名城大学薬学部 准教授 \\ Faculty of Pharmacy, Meijo University, Associate Professor \\ E-mail: tokuda@meijo-u.ac.jp
}

抄 録

本研究では, 難水溶性抗癌剤であるパクリタキセル（PTX）にポリエチレングリコール誘導体を添 加することで調製した徐放性・滞留性を発揮する機能性ナノ結晶（nPTX）を吸入剂として医療応 用すべく，噴霧急速凍結乾燥（SFD）法による粉末製剂化を試み，その有用性について検証した。 賦形剂としてロイシン（Leu）を用いることで，粉末製剤化後もnPTX の粒子物性・PTX の徐放性・ 抗癌活性が十分に保持されるとともに, 優れた肺送達性を発揮する nPTX SFD 微粒子の開発に成功 した。この nPTX SFD 微粒子は, 従来の PTX 製剤である Taxol と比較して, 肺内投与後に PTXを より長時間に渡り肺内に滞留するとともに，肺組織障害性がより軽微であることを明らかにした。 また, nPTX SFD 微粒子の肺内投与後に再構築した nPTXが速やかに肺組織へ移行することを見出 した，肺転移癌モデルマウスを用いた治療評価において, nPTX SFD 微粒子の肺内投与による癌治 療効果の可能性が示唆された.

\begin{abstract}
For application of functional nanocrystals (nPTX) composed of paclitaxel (PTX) and polyethylene glycol derivatives with sustained release and pulmonary retention abilities to inhalation therapy, nPTX-loaded dry powders were newly produced by spray freeze drying (SFD) and their utility as inhaled formulations was investigated in the present study. The nPTX-loaded SFD powders produced with leucine as an excipient were demonstrated to allow reconstruction of nPTX with almost the same particle size distribution, sustained PTX release ability, and anticancer activity as the original ones after their dissolution and to have high aerosol performance for pulmonary delivery through inhalation. Furthermore, the nPTX-loaded SFD powders were clarified to show both more prolonged retention of PTX and milder irritation in the lungs after pulmonary delivery, compared with Taxol, a conventional liquid formulation of PTX. After dissolution of the nPTXloaded SFD powders on the respiratory epithelium, reconstituted nPTX were found to be rapidly transferred to the lung tissue, followed by prolonged pulmonary retention. In therapeutic evaluation with lung metastasis mice, the nPTX-loaded SFD powders were suggested to exhibit anticancer effects in the lungs after pulmonary delivery. These results strongly indicate that the nPTX-loaded SFD powders are promising to apply to inhalation therapy against lung cancer.
\end{abstract}




\section{研究背景と目的}

ナノサイズの薬物結晶核の表面を界面活性剂 で被覆した「ナノクリスタル」は, 難水溶性薬 物の溶解性を改善する製剤技術として近年注目 されている。一方, 筆者はモデル薬物として難 水溶性抗癌剤のパクリタキセル (PTX), 界面 活性剂としてポリエチレングリコール（PEG） 誘導体を用いて調製したナノクリスタル （nPTX）が, 生体内で徐放性・滞留性の機能を 発揮する可能性を見出している。この様な「機 能性ナノクリスタル」が生体内で十分な効果を 発揮するとともにナノ粒子としての保存安定性 を向上するための製剤戦略として, 肺疾患部位 に直接送達可能な吸入粉末製剤化を考案した。 しかし，その実現に向けては，粉末製剂化後も ナノ粒子としての構造・機能を保持するととも に, 吸入剤応用に適した粉体設計を達成しなけ ればならない，そこで本研究では，筆者らが吸 入剤応用を指向して処方・製造条件の最適化を 進めてきた噴霧急速凍結乾燥（SFD）法（Otake H. et al., 2016a, 2016b）を応用して, nPTX を搭 載した中空多孔性粉末微粒子 (nPTX SFD 微粒 子）を調製し, nPTX の構造・機能を保持する とともに肺送達性に優れた機能性吸入粉末剤の 創製を目指した。

\section{研 究 方 法}

\section{1. nPTX 分散液の調製および粉末製剂化}

PTX と PEG 誘導体をクロロホルムに溶解後, 減圧留去により薄膜を形成した，薄膜に水を添 加後, 超音波・遠心・フィルター処理すること でnPTX 分散液を調製した。nPTX 分散液に賦 形剂 (乳糖 $(\mathrm{Lac}) \cdot$ マンニトール $(\mathrm{Man}) \cdot$ ト レハロース $(\mathrm{Tre}) \cdot$ ロイシン $(\mathrm{Leu}) \cdot$ フェニル アラニン (Phe) ) を添加し, 凍結乾燥 (FD) 法または SFD 法により粉末製剂化した。

\section{2. nPTX の再構築性評価（1）：粒子物性}

各粉末製郕を水に溶解することで再構築した
$\mathrm{nPTX}$ の平均粒子径と多分散性指数（PdI）を動 的光散乱法により解析し, 元の nPTX (nPTX 分散液）の值と比較した。

\section{3. nPTX SFD 微粒子の粒子構造評価}

走査型電子顕微鏡（SEM）を用いて，製造し た各 nPTX SFD 微粒子の粒子構造を観察した。

\section{4. nPTX の再構築性評価（2）：PTX の放出 性}

メンブランフィルター（孔径 $0.025 \mu \mathrm{m} ）$ を 含む拡散セルを評価に用い, ドナー側とレセプ ター側にウシ血清アルブミン（BSA）含有リン 酸緩衝液を加えた。PTX 溶液（溶剤としてエ タノールを使用）・Taxol（溶剤としてエタノー ルとクレモホール EL を使用) ・ nPTX 分散液 · nPTX SFD 微粒子の再溶解液をドナー側に添加 後, レセプター側から経時的にサンプルを採取 し, 終了時点でドナー側からもサンプルを採取 した。サンプル中の PTXを高速液体クロマト グラフィー（HPLC）により定量することで, PTXの透過率および回収率を算出した。

\section{5. nPTX の再構築性評価（3）：抗癌活性}

96-well マイクロプレートに播種したヒト肺 癌 (A549) 細胞にPTX 溶液・nPTX 分散液・ nPTX SFD 微粒子再溶解液を添加後, MTT assayを行うことで抗癌活性を評価した。

\section{6. nPTX SFD 微粒子の吸入特性評価}

nPTX SFD 微粒子を充填したカプセルを含む 吸入器をアンダーセン型カスケードインパク ターに装着した後, ポンプを用いて吸引を行っ た。各パーツに沈着した微粒子を回収・定量し て得られたステージ沈着パターンを基にして, カプセルからの放出性の指標值として output efficiency (OE), 肺送達性の指標值として空気 力学的粒子径が $4.7 \mu \mathrm{m}$ 以下の fine particle fraction (FPF), 肺深部送達性の指標值として 空気力学的粒子径が $2.1 \mu \mathrm{m}$ 以下の ultrafine particle fraction (UFPF), 空気力学的質量中位 
径（MMAD）をそれぞれ算出した．

\section{7. nPTX SFD 微粒子肺内投与後の PTX の肺 内分布評価}

nPTX SFD 微粒子を健常マウスの肺内に分散 投与後, 所定の時間に切開した気管から水冷し たリン酸緩衝液を注入・回収することで気管支 肺胞洗浄液（BALF）を採取し，その後に肺を 摘出した。BALFは遠心処理により, 液性画分 と細胞画分に分離した。肺およびBALF（液性 画分・細胞画分）中のPTX をHPLCにより定 量することで PTXの分布量を算出した.

\section{8. nPTX SFD 微粒子肺内投与による肺組織 障害性評価}

nPTX SFD 微粒子を健常マウスの肺内に分散 投与した 24 時間後に 7 と同様の方法で BALF を回収し，液性画分と細胞画分に分離した。肺 組織障害性マーカーとして, 液性画分中の乳酸 脱水素酵素 $(\mathrm{LDH})$ 漏出量ならびに細胞画分 中の細胞数に着目し，定量用キットおよびイ メージベースサイトメーターを用いてそれぞれ 測定した。

\section{9. nPTX SFD 微粒子肺内投与による肺癌治 療評価}

ルシフェラーゼ安定発現マウス大腸癌 （colon26/Luc）細胞を健常マウスに尾静脈内投 与することで樹立した肺転移モデル担癌マウス を評価に用いた。 colon26/Luc 細胞の播種後 4 ・ 8 日目にnPTX SFD 微粒子をマウス肺内に分散 投与し，播種後 $7 \cdot 9 \cdot 11$ 日目にルシフェラー ゼ発現に由来する発光をリアルタイム in vivo イメージングシステムを用いて検出し, 肺内発 光強度（癌細胞数に相当）を定量解析した。播 種後 11 日目の発光検出終了後に, 副作用の指 標として体重を測定してから肺を摘出し，肺重 量（癌細胞数に相当）を測定した。

\section{研 究成果}

\section{1. 粉末製剂化後の nPTX の粒子物性}

PEG 誘導体の脂溶性部分の構造がリン脂質 よりもトコフェロールあるいはコレステロール の方が，またPTX と PEG 誘導体の重量比を 1 に設定することで，粒子径がより小さくまた均 一性がより高いnPTXを得られることを見出し た。肺内投与後の nPTXの肺内滞留作用につい て, PEG 誘導体の PEG 部分の分子量が 1000 よ りも2000あるいは 5000 の方が，また PEG 誘 導体の脂溶性部分の構造がトコフェロールより もコレステロールの方がそれぞれ効果的である ことを明らかにした。ささら FD法による賦形 片の検討結果から，糖（ $\mathrm{Lac} \cdot \mathrm{Man} \cdot \mathrm{Tre} ） よ り$ も疎水性アミノ酸（Leu・Phe）の方が粉末製 剤化後に nPTX の粒子径をより長期に渡り維持 できることが示唆された。これらの結果より， $\lceil\mathrm{PEG}$ 誘導体：PEG 部分の分子量が 2000 で脂 溶性部分の構造がコレステロールのもの, PTX に対する PEG 誘導体の重量比：1, 賦形剤： Leu」の処方を基にして, nPTX SFD 微粒子の 製造を進めた。

nPTX 含量を 10-40\%の範囲で変化させて製 造した nPTX SFD 微粒子について, 溶解後に再 構築した nPTX の平均粒子径および PdI の值が nPTX 含量によらず粉末製剂化前の值と同様で あったことから（表 1)，少なくともnPTX含 量が $40 \%$ までは粉末製剤化後に nPTX の粒子 物性を保持できることが明らかとなった。

Table 1 Particle property of nPTX constituted before and after powderization by SFD.

\begin{tabular}{|l|c|c|}
\hline \multicolumn{1}{|c|}{ Formulation name } & $\begin{array}{c}\text { Mean particle } \\
\text { size }(\mathrm{nm})\end{array}$ & PdI \\
\hline nPTX SL & $171 \pm 2$ & $0.160 \pm 0.012$ \\
\hline nPTX (10\%) DPSL & $187 \pm 3$ & $0.166 \pm 0.004$ \\
\hline nPTX (20\%) DPSL & $185 \pm 1$ & $0.151 \pm 0.019$ \\
\hline nPTX (40\%) DPSL & $166 \pm 2$ & $0.147 \pm 0.015$ \\
\hline
\end{tabular}

SL: solution (or dispersion), DPSL: SFD powder solution. Each value represents the mean \pm S.D. $(n=3)$. 

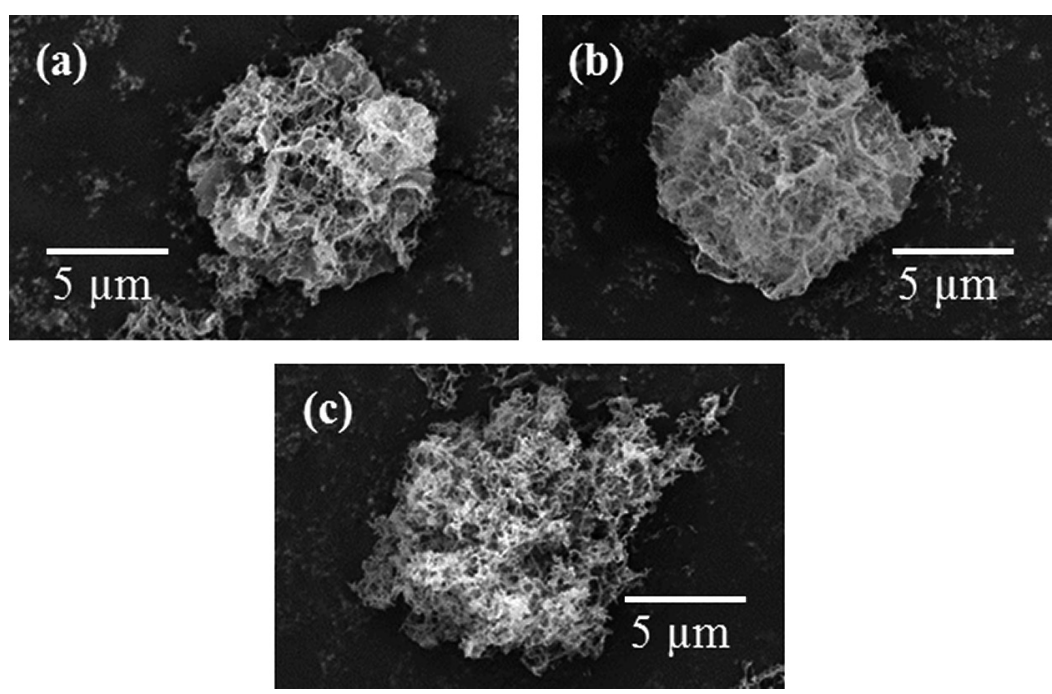

Fig. 1 Scanning electron microscope images of nPTX-loaded SFD powders: (a) nPTX (10\%) DP, (b) nPTX (20\%) DP, (c) nPTX (40\%) DP. DP: SFD powder.

\section{2. nPTX SFD 微粒子の粒子構造}

上記の nPTX SFD 微粒子について SEM 観察 したところ, nPTX 含量による大きな違いは認 められず，直径が 10-20 $\mu \mathrm{m}$ で SFD 法特有の中 空多孔性に富む球状微粒子であることを確認で きた（図 1)。ただし, nPTX含量が $40 \%$ の nPTX SFD 微粒子は保存時に吸湿しやすい傾向 が見られたため, 以下の評価では, nPTX 含量 が 10\%あるいは $20 \%$ の nPTX SFD 微粒子を用 いた。

\section{SFD 法による粉末製剤化後の nPTX から の PTX 放出性}

添加後 180 分に打ける PTX 透過率（図 2(a)） について, PTX 単独溶液および Taxol で約 5\% であったのに対し, nPTX 分散液およびnPTX SFD 微粒子の再溶解液で約 $1 \%$ と低く, nPTX からの PTX 徐放性が示唆された。また回收率 について, PTX 単独溶液で $10 \%$ 以下, Taxol で $20 \%$ 以下と低く, 試験液中に存在する遊離 PTX の析出あるいはフィルター・擋汼子・試験容器 への吸着の影響と考えられたのに対し, nPTX 分散液で約 $120 \%$, nPTX SFD 微粒子の再溶解 液で約 70\% と前者よりも顕著に高く, BSAを
含む試験液中でもnPTX の構造が維持されてい ることが窥えた。これらの結果より，粉末製剤 化後も nPTX の構造安定性ならびに PTX 徐放 性が保持されることが明らかとなった。

\section{SFD 法による粉末製剤化後の nPTX の抗 癌活性}

$n$ PTX 分散液添加後の細胞生存率 - 処理濃度 パターンは PTX 単独溶液添加後の結果と異な り, PTX 単独溶液と比較した殺細胞作用が低 処理濃度側ではより弱いのに対し, 高処理濃度 側ではより強い傾向を示した（図 2(b)）。nPTX がこのような細胞生存率－処理濃度パターンを 示した理由として, nPTX からのPTXの徐放性 が寄与するものと推察される。また, nPTX SFD 微粒子の再溶解液添加後についても, $\mathrm{nPTX}$ 分散液添加後と同様の細胞生存率 - 処理 濃度パターンが得られ, nPTX 含量が $10 \%$ と 20\%で大きな違いは見られなかった。これら の結果より, nPTX 含量が少なくとも $20 \%$ まで は粉末製剂化後もnPTX 特有の抗癌活性が保持 されることが明らかとなった。

\section{5. nPTX SFD 微粒子の吸入特性}

吸入特性の指標值の解析結果（表 2) におい 

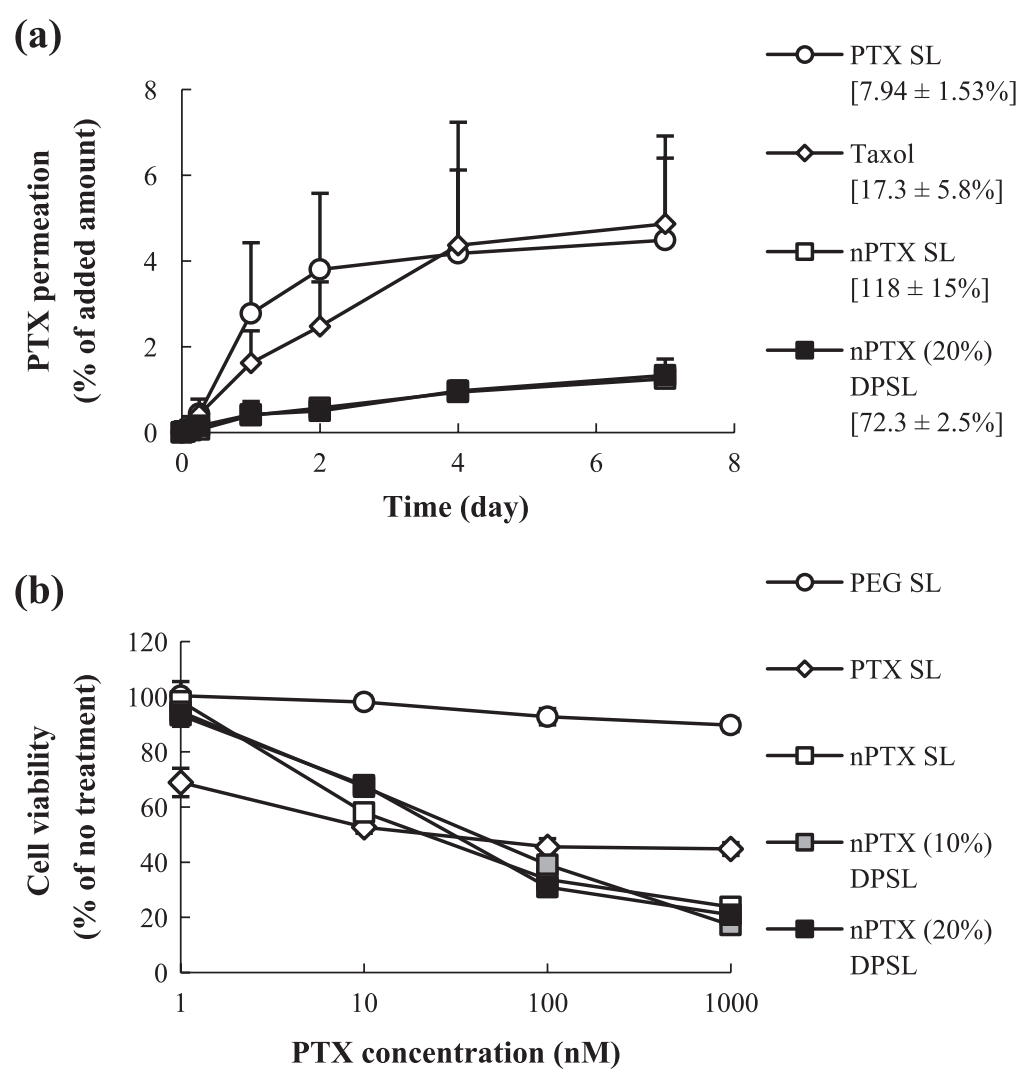

Fig. 2 (a) PTX release and (b) anticancer activity of nPTX constituted before and after powderization by SFD. PEG: polyethylene glycol derivative, SL: solution (or dispersion), DPSL: SFD powder solution. Each value represents the mean \pm S.D. ((a) $n=3$, (b) $n=4)$. The value shown below each PTX formulation name in (a) is PTX recovery (\% of added amount). In (b), the data for PEG SL were plotted as PTX concentration in nPTX SL with the same PEG concentration.

Table 2 Aerosol performance of nPTX-loaded SFD powders for inhalation.

\begin{tabular}{|l|c|c|c|c|}
\hline Formulation & $\begin{array}{c}\text { OE } \\
\text { name }\end{array}$ & $\begin{array}{c}\text { FPF } \\
(\%)\end{array}$ & $\begin{array}{c}\text { UFPF } \\
(\%)\end{array}$ & $\begin{array}{c}\text { MMAD } \\
(\mu \mathrm{m})\end{array}$ \\
\hline Leu DP & $\begin{array}{c}91.7 \\
\pm 4.4\end{array}$ & $\begin{array}{c}68.9 \\
\pm 3.4\end{array}$ & $\begin{array}{c}49.4 \\
\pm 4.0\end{array}$ & $\begin{array}{c}0.83 \\
\pm 0.15\end{array}$ \\
\hline nPTX $(10 \%)$ & $\begin{array}{c}90.5 \\
\text { DP }\end{array}$ & $\begin{array}{c}68.7 \\
\pm 4.2\end{array}$ & $\begin{array}{c}44.7 \\
\pm 4.2\end{array}$ & $\begin{array}{c}1.22 \\
\pm 0.13\end{array}$ \\
\hline nPTX $(20 \%)$ & $\begin{array}{c}92.1 \\
\pm 4.8\end{array}$ & $\begin{array}{c}54.5 \\
\pm 3.2\end{array}$ & $\begin{array}{c}25.8 \\
\pm 1.7\end{array}$ & $\begin{array}{c}2.68 \\
\pm 0.19\end{array}$ \\
\hline
\end{tabular}

DP: SFD powder. Each value represents the mean \pm S.D. $(n=3)$.

て, nPTX 含量が 10\%の nPTX SFD 微粒子では, OE で約 90\%, FPF で約 70\%, UFPF で約 45\%, MMAD で約 $1 \mu \mathrm{m}$ の值が得られ，賦形剤として
用いた Leuのみから成る SFD 微粒子と同様の 優れた吸入特性を示した。一方, nPTX 含量が $20 \%$ の SFD 微粒子では, nPTX 含量が $10 \%$ の SFD 微粒子と比較して, FPF およびUFPF がよ り低值,また MMADがより高值を示し, 肺送 達性が劣る結果となった。これらの結果より, nPTX 含量を $10 \%$ に留めることで, 肺送達に適 した nPTX SFD 微粒子が得られることが明らか となった

\section{6. nPTX SFD 微粒子肺内投与後の PTX の肺 内分布}

予備検討において, Taxolの投与では肺から PTXが速やかに消失し 8 時間後には検出でき なかったのに対し, nPTX 分散液の投与では PTXがより長時間肺内に滞留し 72 時間後でも 
肺内で PTX を検出できた。肺内での PTXの分 布をより細かく評価したところ，投与 1 時間後 に Taxolの投与ではBALF の液性画分と肺組織 にPTXがほほ同程度分布していたのに対し, nPTX 分散液の投与では BALF の液性画分への PTXの分布は極微量で大部分のPTXが肺組織 に移行していた（図3）。その後もnPTX 分散 液の投与では，PTXが長時間に渡り肺組織に 分布していた。BALFの細胞画分については, Taxolよりも nPTX 分散液の投与の方が PTXの 分布量が多いものの，投与 1 時間後で投与量の 約 $5 \%$ 程度と微量であった。nPTX SFD 微粒子 の投与でも, nPTX 分散液およびnPTX SFD 微 粒子の再溶解液と同様に, PTXが長時間に渡
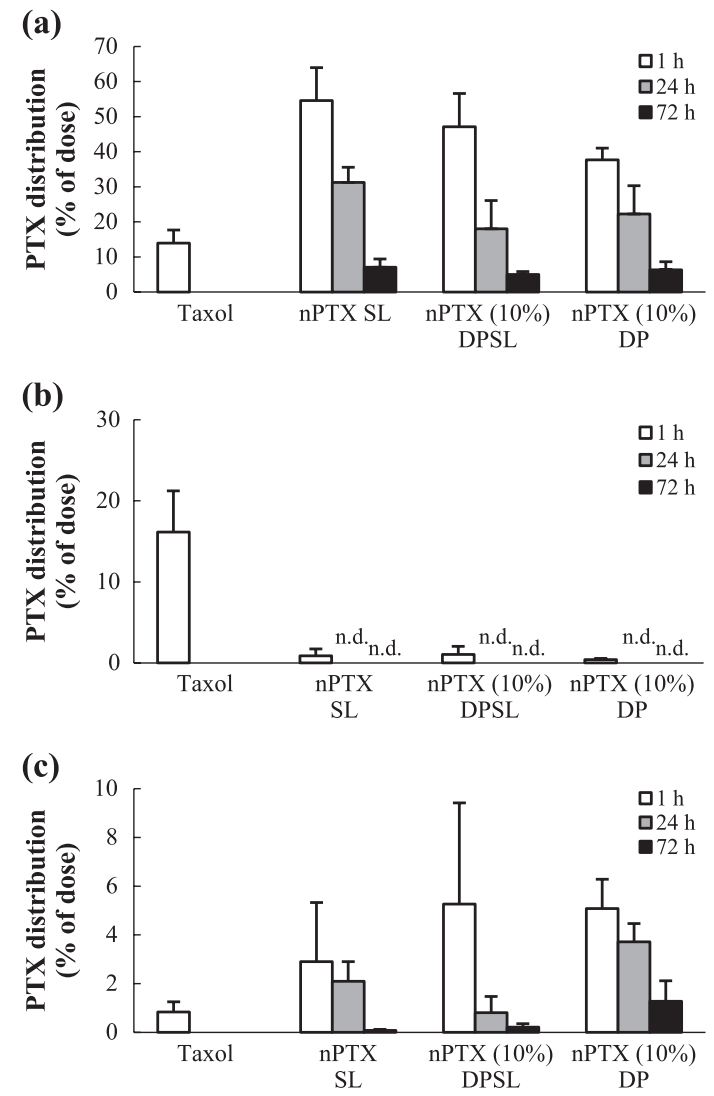

Fig. 3 Pulmonary PTX distribution after intratracheal administration of nPTX-loaded SFD powders into healthy mice: (a) lung tissue, (b) BALF (supernatant fraction), (c) BALF (cell fraction). SL: solution (or dispersion), DPSL: SFD powder solution, DP: SFD powder, n.d.: not detected. Each value represents the mean \pm S.D. $(n=5-8)$.
り肺組織に分布していた。これらの結果より， nPTXが有する肺組織移行性ならびに滞留性の 機能が粉末製剤化後も保持されることが明らか となった。

\section{7. nPTX SFD 微粒子肺内投与による肺組織} 障害性

BALF 中の LDH 漏出量（図 4）に関して, Taxol $\cdot$ nPTX 分散液 - nPTX SFD 微粒子投与群 ともに PTXの投与量増加に伴ってより高值を 示す傾向が見られたものの，亲ガティブコント ロールの未好理群と有意な差はなく，またポジ ティブコントロールのドデシル硫酸ナトリウム （SDS）投与群と比較して有意に低值であった。 一方， PTXとして $50 \mu \mathrm{g}$ の投与量における BALF 中の細胞数（図 4）に関して， Taxol 投 与群ではSDS 投与群よりも高值を示したのに 対し, nPTX 分散液およびnPTX SFD 微粒子投 与群では未投与群と同様の值であった。これら

(a)
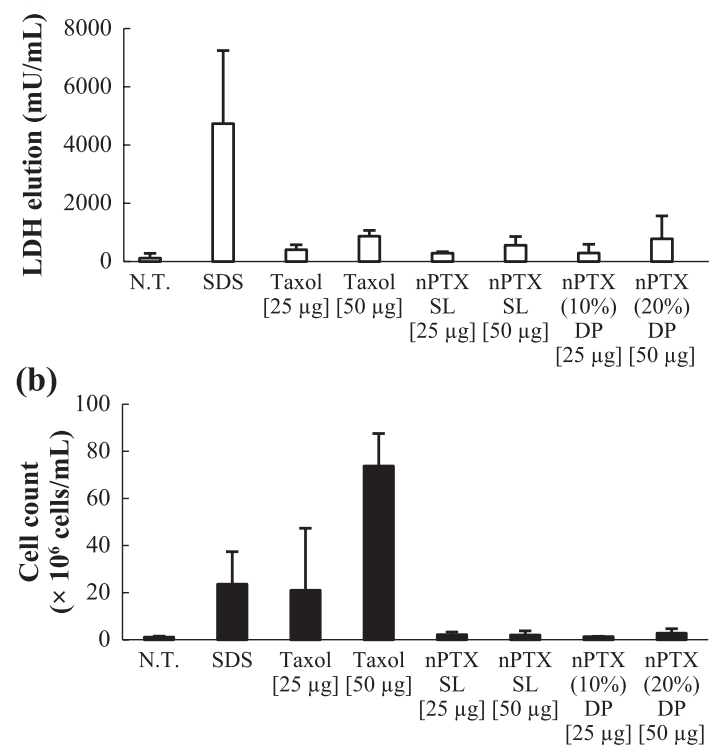

Fig. 4 Pulmonary injury caused by intratracheal administration of nPTX-loaded SFD powders into healthy mice: (a) LDH elution, (b) cell count. N.T.: no treatment, SL: solution (or dispersion), DP: SFD powder. Each value represents the mean $\pm \mathrm{S}$. D. $(n=3-6)$. The value shown below each PTX formulation name is PTX dose. 


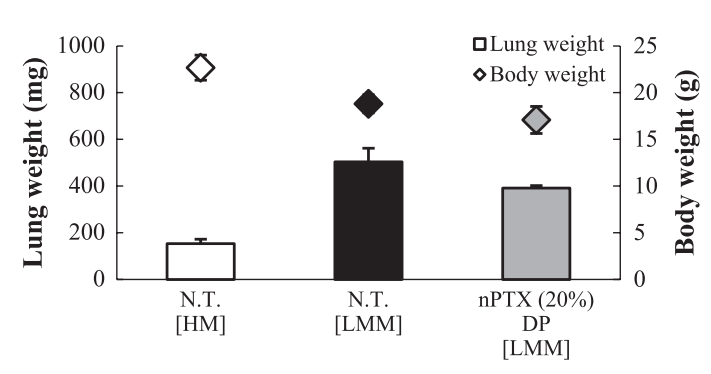

Fig. 5 Therapeutic effects of intratracheal administration of nPTX-loaded SFD powders in lung metastasis mice: lung weight and body weight on Day 11 after inoculation. N.T.: no treatment, DP: SFD powder, HM: healthy mice, LMM: lung metastasis mice. Each value represents the mean \pm S.D. $(n=3-5)$.

の結果より, nPTX 分散液と同様にnPTX SFD 微粒子の肺内投与は，Taxol の肺内投与よりも 肺組織障害性が低く比較的軽微であることが明 らかとなった。

\section{8. nPTX SFD 微粒子肺内投与による肺癌治 療効果}

担癌マウスにおける肺内発光強度の経日推移 について, 日数経過に伴った肺内発光強度の増 加傾向が見られ, 肺内での癌細胞の増殖を確認 できた。 マウス個体間の肺内発光強度のばらつ きが大きいためにnPTX SFD 微粒子の投与の有

\section{外部 発表成果}

\section{口頭・ポスター発表}

1. Okuda T., Ito T., Niwa N., Okamoto H., "Development of functional paclitaxel nanocrystals and its application to dry powder formulation for inhalation", 6th FIP Pharmaceutical Sciences World Congress 2017 (Stockholm, Sweden, May 21-24, 2017) P-B-034.
無で結果に明確な差は認められなかったもの の, 播種後 11 日目の肺内発光強度の值が nPTX SFD 微粒子投与群で全体的に小さい傾向が見 られ，肺癌治療効果の可能性が窅えた。播種後 11 日目の肺重量測定の結果（図 5）に扔いて, 健常マウスと比較して担癌マウスでは癌細胞の 増殖により肺重量が約 $350 \mathrm{mg}$ 増加したのに対 し, nPTX SFD 微粒子の投与によりその増加が 有意に抑えられたことから, 肺内発光強度の結 果と同様に肺癌治療効果の可能性が示唆され た。一方, 担癌マウスの体重（図 5）について, nPTX SFD 微粒子の投与による顕著な変化は見 られなかったことから, 副作用は比較的軽微で あることが示唆された。

\section{参考文献}

[1] Otake H., Okuda T., Hira D., Kojima H., Shimada Y., Okamoto H., Inhalable spray-freeze-dried powder with L-leucine that delivers particles independent of inspiratory flow pattern and inhalation device, Pharmaceutical Research, 33 (2016a) 922-931.

[2] Otake H., Okuda T., Okamoto H., Development of spray-freeze-dried powders for inhalation with high inhalation performance and antihygroscopic property, Chemical and Pharmaceutical Bulletin, 64 (2016b) 239-245.

2. 成田 幹也, 奥田 知将, 山岸千恵, 岡本 浩一, “肺内投与後の機能性パクリタキセルナノ結 晶の体内動態評価および吸入粉末製剂化の 検討”, 第 33 回日本 DDS 学会 (Kyoto, Jul. 6-7, 2017) 1-E-5.

3. 奥田 知将, 成田 幹也, 山岸千恵, 岡本浩一, “噴霧急速凍結乾燥法を基盤としたナノ結晶 吸入粉末凨の開発”, 第 34 回日本 DDS 学会 （Nagasaki, June 21-22, 2018）2-E-6. 